\title{
Dental Trauma and Treatment Needs among Footballers in Baghdad City
}

\author{
Yasir B. Abd Ali ${ }^{1}$, Eman K. Chaloob ${ }^{2}$ \\ ${ }^{1}$ M.Sc. Student, Department of Pediatric and preventive Dentistry, College of Dentistry, University of Baghdad \\ ${ }^{2}$ Assistant Professor, Department of Pediatric and Preventive Dentistry, College of Dentistry, University of Baghdad
}

\begin{abstract}
Oral health is an important element of overall health, well-being and quality of life. The nexus between sport and oral health has largely been investigated through studies focused on the risk of trauma to oral health. The purpose of this study to estimate the prevalence and severity of dental trauma in Iraqi footballers. This study included 403 Iraqi males footballers aged from 18-32 years. The cases were recruited from 18 club in Baghdad city. The results of this study show high percentage of trauma free was recorded among Luxation (99.50\%) and enamel and dentine with pulp exposure EDP (99.26\%) with all age group followed by Concussion (97.77\%) and enamel and dentine ED fracture (96.77\%) and the lowest percent recorded in enamel fracture $E(94.79 \%)$. In Luxation trauma type a significant differences $(P=0.027)$ was found according to age and duration of playing while high significant differences $(P=0.019)$ was found in concussion type. From current study concluded high percent of caries injuries in Iraqi footballers.
\end{abstract}

Keywords: Dental trauma, footballer

\section{Introduction}

Football is one of the most popular team sports in the world, with approximately 200.000 professional and 240 million amateur players $(1,2)$. In iraq, football is the most popular sport and the Iraqi football association seeks the developments in the football that reflect the development of the country in sport in general (3). A high performance of a soccer player can only be attained by a healthy body condition. Generally, oral health is very important for overall health and quality of life (4). Despite the popular belief that soccer is not a violent sport, it presents a high risk of injuries compared to athletes, including oral and craniofacial injuries (5). However, athletes may have poor oral health including high levels of dental erosion and dental trauma (6). Poor oral health can reduce quality of life and induce a systemic inflammatory response (7). The risk occurs due to the aggressive defense system, resulting in greater possibility of traumatic accidents (8). Injury rates vary greatly depending on the size of the sample, the sample's geographic location, the ages of the participants, and the specific sports involved in the study (9). Rates of traumatic dental injuries also differ in regards to the athlete's level of competition; less-professional athletes exhibit a higher prevalence of sports-related injuries (10). According to the International Dental Federation, there are two risk categories for dental trauma: high-risk sports, such as football, ice hockey, inline-skating, skate-boarding, lacrosse, rugby and mountain-biking; and medium-risk sports, such as basketball, team handball, squash, gymnastics, water polo and soccer (1). The role of dentistry in the sports is important because it provides the athlete optimal oral health conditions which in turn can contribute to achievement of optimal performance during competition (11). Sports dentistry is the prevention of oral/facial athletic injuries and related oral diseases and manifestations. Sports dentistry has two major components; the first is the treatment of orofacial injuries and the second is the prevention of sports-related or facial injuries (12).

\section{Subjects and Methods}

This study was carried out among adult males professional football players with aged range (18-32) years old in Baghdad city governorate in Iraq. The sample involved 403 males footballers were recruited from 18 club in Baghdad city during November 2016 till the end of March 2017. These clubs classified into two categories: excellent degree club have 203 footballer and first degree club have 200 footballer according to Iraqi football association. Dental trauma were diagnosed and recorded according to the index (13). Clinical examination was conducted using plane mouth mirror and dental explorer. In regarding to the surface examination started with the mesial surface, followed by the occlusal, distal, buccal and lingual for all teeth examined (13). The treatment required was registered, diagnosis and recording were according to criteria of WHO (14).

\section{Results and Discussion}

Table (1) shows trauma types according to three age group. The percentage of trauma free among the sample is $88.34 \%$ (356 subjects). Differences was statistically insignificant existed between three age groups in enamel fracture $\mathrm{E}$, enamel and dentine fracture ED, enamel and dentine with pulp exposure EDP, and Concussion ( $p>0.05)$ except in Luxation was significant differences $(\mathrm{P}=0.027)$.

Table 1: distribution of trauma types according to age group

\begin{tabular}{|c|c|c|c|c|c|}
\hline Trauma types & Age & No. & \multicolumn{2}{|c|}{ trauma Free } & p-value \\
\cline { 2 - 5 } & (Year) & & No. & $\%$ & \\
\hline \multirow{4}{*}{ E fracture } & $18-22$ & 193 & 185 & 95.85 & \\
\cline { 2 - 5 } & $23-27$ & 144 & 135 & 93.75 & \multirow{2}{*}{0.652} \\
\cline { 2 - 5 } & $28-32$ & 66 & 62 & 93.94 & \\
\cline { 2 - 5 } & Total & 403 & 382 & 94.79 & \\
\hline \multirow{5}{*}{ ED fracture } & $18-22$ & 193 & 187 & 96.89 & \multirow{3}{*}{0.205} \\
\cline { 2 - 5 } & $23-27$ & 144 & 137 & 95.14 & \\
\cline { 2 - 5 } & $28-32$ & 66 & 66 & 100.00 & \\
\cline { 2 - 5 } & Total & 403 & 390 & 96.77 & \\
\hline EDP exposure & $18-22$ & 193 & 191 & 98.96 & \\
\hline
\end{tabular}

Volume 6 Issue 12, December 2017 


\section{International Journal of Science and Research (IJSR) \\ ISSN (Online): 2319-7064}

Index Copernicus Value (2016): 79.57 | Impact Factor (2015): 6.391

\begin{tabular}{|c|c|c|c|c|c|}
\hline & $23-27$ & 144 & 143 & 99.31 & 1.00 \\
\hline & $28-32$ & 66 & 66 & 100.00 & \\
\hline & Total & 403 & 400 & 99.26 & \\
\hline \multirow{4}{*}{ Concussion } & $18-22$ & 193 & 189 & 97.93 & \multirow{3}{*}{0.819} \\
\hline & $23-27$ & 144 & 141 & 97.92 & \\
\hline & $28-32$ & 66 & 64 & 96.97 & \\
\hline & Total & 403 & 394 & 97.77 & \\
\hline \multirow{4}{*}{ Luxation } & $18-22$ & 193 & 193 & 100.00 & \multirow{3}{*}{0.027} \\
\hline & $23-27$ & 144 & 144 & 100.00 & \\
\hline & $28-32$ & 66 & 64 & 96.97 & \\
\hline & Total & 403 & 401 & 99.50 & \\
\hline \multirow{4}{*}{ Total } & $18-22$ & 193 & 174 & 90.16 & \multirow{3}{*}{0.515} \\
\hline & $23-27$ & 144 & 124 & 86.11 & \\
\hline & $28-32$ & 66 & 58 & 87.88 & \\
\hline & Total & 403 & 356 & 88.34 & \\
\hline
\end{tabular}

\begin{tabular}{|c|c|c|c|c|c|}
\hline \multirow{4}{*}{ Total } & $5-8$ & 124 & 124 & 100.00 & 0.024 \\
\cline { 2 - 5 } & $9-12$ & 62 & 60 & 96.77 & \\
\cline { 2 - 5 } & Total & 403 & 401 & 99.50 & \\
\cline { 2 - 5 } & $1-4$ & 217 & 193 & 88.94 & \multirow{3}{*}{0.101} \\
\cline { 2 - 5 } & $5-8$ & 124 & 113 & 91.13 & \\
\cline { 2 - 5 } & $9-12$ & 62 & 50 & 80.65 & \\
\cline { 2 - 5 } & Total & 403 & 356 & 88.34 & \\
\hline
\end{tabular}

Table 4: distribution of trauma types according to club type

\begin{tabular}{|c|c|c|c|c|c|}
\hline \multirow{2}{*}{ Trauma types } & \multirow{2}{*}{ Club type } & \multirow{2}{*}{ No. } & \multicolumn{2}{|c|}{ trauma Free } & $\mathrm{P}_{8}$ \\
\hline & & & No. & $\%$ & \multirow{3}{*}{0.479} \\
\hline \multirow{3}{*}{ E fracture } & Excellent & 203 & 194 & 95.57 & \\
\hline & First degree & 200 & 188 & 94.00 & \\
\hline & Total & 403 & 382 & 94.79 & \\
\hline \multirow{3}{*}{ ED fracture } & Excellent & 203 & 193 & 95.07 & \multirow[t]{2}{*}{0.052} \\
\hline & First degree & 200 & 197 & 98.50 & \\
\hline & Total & 403 & 390 & 96.77 & \\
\hline \multirow{3}{*}{ EDP exposure } & Excellent & 203 & 201 & 99.01 & \multirow[t]{2}{*}{1.00} \\
\hline & First degree & 200 & 199 & 99.50 & \\
\hline & Total & 403 & 400 & 99.25 & \multirow{3}{*}{0.019} \\
\hline \multirow{3}{*}{ Concussion } & Excellent & 203 & 202 & 99.51 & \\
\hline & First degree & 200 & 192 & 96.00 & \\
\hline & Total & 403 & 394 & 97.77 & \\
\hline \multirow{3}{*}{ Luxation } & Excellent & 203 & 201 & 99.01 & \multirow[t]{2}{*}{0.499} \\
\hline & First degree & 200 & 200 & 100.00 & \\
\hline & Total & 403 & 401 & 99.50 & \multirow{3}{*}{0.920} \\
\hline \multirow{3}{*}{ Total } & Excellent & 203 & 179 & 88.18 & \\
\hline & First degree & 200 & 177 & 88.50 & \\
\hline & Total & 403 & 356 & 88.34 & \\
\hline
\end{tabular}

Table 2: distribution of trauma types according to education level

\begin{tabular}{|c|c|c|c|c|c|}
\hline \multirow{2}{*}{$\begin{array}{c}\text { Trauma } \\
\text { types }\end{array}$} & \multirow{2}{*}{$\begin{array}{c}\text { Education } \\
\text { level }\end{array}$} & \multirow{2}{*}{ No. } & \multicolumn{2}{|c|}{ trauma Free } & \multirow{2}{*}{ P-value } \\
\hline & & & No. & $\%$ & \\
\hline \multirow{4}{*}{ E fracture } & 1 & 134 & 126 & 94.03 & \multirow{3}{*}{0.410} \\
\hline & 2 & 184 & 173 & 94.02 & \\
\hline & 3 & 85 & 83 & 97.65 & \\
\hline & Total & 403 & 382 & 94.79 & \\
\hline \multirow{4}{*}{$\begin{array}{l}\text { ED } \\
\text { fracture }\end{array}$} & 1 & 134 & 129 & 96.27 & \multirow[b]{3}{*}{0.935} \\
\hline & 2 & 184 & 178 & 96.74 & \\
\hline & 3 & 85 & 83 & 97.65 & \\
\hline & Total & 403 & 390 & 96.77 & \\
\hline \multirow{4}{*}{$\begin{array}{c}\text { EDP } \\
\text { exposure }\end{array}$} & 1 & 134 & 133 & 99.25 & \multirow[t]{3}{*}{1.000} \\
\hline & 2 & 184 & 182 & 98.91 & \\
\hline & 3 & 85 & 85 & 100 & \\
\hline & Total & 403 & 400 & 99.25 & \\
\hline \multirow{4}{*}{ Concussion } & 1 & 134 & 130 & 97.01 & \multirow[t]{3}{*}{0.678} \\
\hline & 2 & 184 & 181 & 98.37 & \\
\hline & 3 & 85 & 83 & 97.65 & \\
\hline & Total & 403 & 394 & 97.77 & \\
\hline \multirow{4}{*}{ Luxation } & 1 & 134 & 134 & 100.00 & \multirow[t]{3}{*}{0.693} \\
\hline & 2 & 184 & 182 & 98.91 & \\
\hline & 3 & 85 & 85 & 100.00 & \\
\hline & Total & 403 & 401 & 99.50 & \\
\hline \multirow{4}{*}{ Total } & 1 & 134 & 116 & 86.57 & \multirow[t]{3}{*}{0.320} \\
\hline & 2 & 184 & 161 & 87.50 & \\
\hline & 3 & 85 & 79 & 92.94 & \\
\hline & Total & 403 & 356 & 88.34 & \\
\hline
\end{tabular}

Table 3: distribution of trauma types according to duration

\begin{tabular}{|c|c|c|c|c|c|}
\hline \multirow{2}{*}{$\begin{array}{c}\text { Trauma } \\
\text { types }\end{array}$} & \multirow{2}{*}{$\begin{array}{l}\text { Duration of } \\
\text { playing }\end{array}$} & \multirow[t]{2}{*}{ No. } & \multicolumn{2}{|c|}{ trauma Free } & \multirow[t]{2}{*}{ P-value } \\
\hline & & & No. & $\%$ & \\
\hline \multirow{4}{*}{ E fracture } & $1-4$ & 217 & 207 & 95.39 & \multirow[b]{3}{*}{0.222} \\
\hline & $5-8$ & 124 & 119 & 95.97 & \\
\hline & $9-12$ & 62 & 56 & 90.32 & \\
\hline & Total & 403 & 382 & 94.79 & \\
\hline \multirow{4}{*}{ ED fracture } & $1-4$ & 217 & 209 & 96.31 & \multirow{3}{*}{0.926} \\
\hline & $5-8$ & 124 & 121 & 97.58 & \\
\hline & $9-12$ & 62 & 60 & 96.77 & \\
\hline & Total & 403 & 390 & 96.77 & \multirow{4}{*}{0.732} \\
\hline \multirow{4}{*}{$\begin{array}{c}\text { EDP } \\
\text { exposure }\end{array}$} & $1-4$ & 217 & 214 & 98.62 & \\
\hline & $5-8$ & 124 & 124 & 100.00 & \\
\hline & $9-12$ & 62 & 62 & 100.00 & \\
\hline & Total & 403 & 400 & 99.25 & \\
\hline \multirow{4}{*}{ Concussion } & $1-4$ & 217 & 213 & 98.16 & \multirow{3}{*}{0.735} \\
\hline & $5-8$ & 124 & 121 & 97.58 & \\
\hline & $9-12$ & 62 & 60 & 96.77 & \\
\hline & Total & 403 & 394 & 97.77 & \\
\hline Luxation & $1-4$ & 217 & 217 & 100.00 & \\
\hline
\end{tabular}

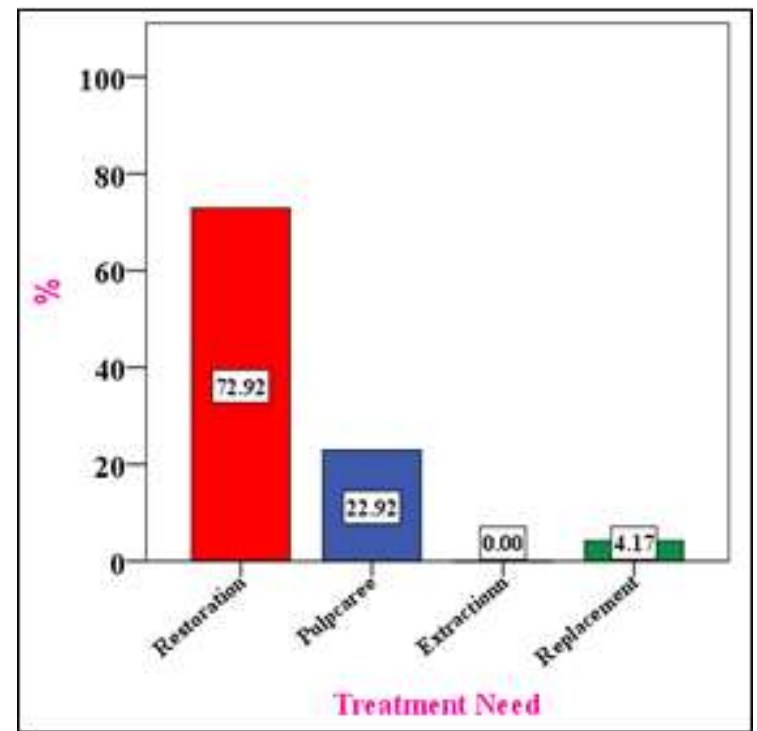

Figure 1: reveals the percentages of footballers who were in needs of dental treatment index and mean number of teeth in each category

This study is the first study to demonstrate the oral health status of football players in Baghdad city concerning the 403 males footballers aged range 18-32 years were randomly selected. So, results of the present study can be considered as a base line data for comparison with other studies in Iraqi Government and different parts of the world.

Injuries are very common in sports, especially in those modalities involving more speed and close contact between athletes, which are more susceptible to facial and dental trauma (15). The main causes of sports-related dental trauma 


\section{International Journal of Science and Research (IJSR) \\ ISSN (Online): 2319-7064}

Index Copernicus Value (2016): 79.57 | Impact Factor (2015): 6.391

are falls and collisions with people or objects. Greater speed and contact increase the risk of trauma. Soccer was found to be associated with high risks of facial and dental injuries (16) . Study by Correa and co-workers reported that $71.1 \%$ of the professional soccer having observed dental injuries during practice. This finding is in accordance with those of several authors that pointed soccer as a violent sport with high risk of injuries $(5 ; 17)$.

Results of current study showed the percentage of trauma free among the sample is $88.34 \%$ (356 subjects). High percentage of trauma free with age was recorded among Luxation (99.50\%) and EDP exposure (99.26\%) with all age group followed by Concussion $(97.77 \%)$, ED fracture $(96.77 \%)$ and $\mathrm{E}$ fracture $(94.79 \%)$. This result was in line with Correa et al, 2010 that reported the most frequent kinds of dental trauma were dental fractures and luxation, which are considered the most serious types of dental trauma. Such finding could be due to the fact that most severe injuries are easily perceived, while less severe injuries, like enamel fractures, could be underestimated. These finding was lower that reported by Flores (19) and higher that of Ilhan (20) that revealed fractures were the most common injury with percent $(88.57 \%)$.

The percent of trauma free according to education level in current study was found high percent in all trauma type with all education level especially in third level of education. This finding is lower to that obtained by Ilhan (20) that found 35 $(10.2 \%)$ soccer players reported the occurrence of some type of dental injury during soccer practice according to education level.

Present study showed the trauma type according to duration of playing was high in Luxation, EDP exposure, Concussion, and fracture. These results are in accordance with a study of Erhan and co-workers (16) who demonstrated that trauma type (Luxation) was significantly increased during a 1-year period of playing. The mandatory wear of mouthguards in various sports like American football, rugby and boxing, makes it possible the prevention of dental injuries (21). However, in soccer, mouthguard wear is not mandatory; consequently, the incidence of dental trauma is higher than other sports considered more violent, like martial arts (22). These injuries can be prevented by protection of buccal region with mouthguards and by other strategies, like application of preventive programs in players focused in the adherence to the match rules and spirit of fair play (1). Studies have demonstrated that most players do not have sufficient knowledge of prevention of dental injuries and mouthguards (23). Forty-eight percent of the physicians in charge for medical departments in soccer teams in this study had no knowledge of mouthguards, and this could impair the possibilities of dental trauma prevention.

Chantaramanee and co-workers (24) reported that facial and oral injuries suffered by $8 \%$ of soccer players which was lower, compared with study by Ferrari et al, 2002 that found the mean of $23 \%$ reported in Brazilian soccer players. Fracture of permanent teeth is the most serious of all dental injuries. The prognosis depends on the damages taken at the place of accident or the time immediately after the fracture. An appropriate treatment plan after injury is important for successful tooth replantation and the knowledge of emergency services plays an important role in this aspect (19). Replantation is the treatment of choice, but cannot always be carried out immediately. An appropriate treatment plan after an injury is important for a good prognosis (25). In this study, none of the soccer players and their staff does not know how to manage on these injuries. Therefore, some treatments, prevention guidelines and strategies of oral health promotion regarding to dental caries, periodontal status and management of facial and oral injuries would be necessary.

Result of present study revealed that the high percent of restoration type of footballers that need treatment followed by pulp care and replacement. This result in line with Papakosta et al (17) which reported that 103 of the 173 patients requiring restoration treatment for trauma during an 8-year period were amateur soccer players and these findings is disagreement with Paulo et al, 2014 that reported the high percent of extractions type - $51 \%$ that need treatment. This study is the first study to represented information about dental treatment need among footballers therefore, on previous data to compare with finding of the study. The high need for dental treatment may be related to income, lack of oral health promotion programs and negligence treatment of those footballers (6). Information obtained can aid in conducting preventive programs and evaluating future efforts aimed to improve the oral health condition among footballers in our society. Preventive programs need to be initiated for improvement of dental knowledge, behavior and attitude of footballers.

\section{References}

[1] Junge A, Rösch D, Peterson L, Graf-Baumann T, Dvorak J. Prevention of soccer injuries: a prospective intervention study in youth amateur players. Am J Sports Med, 2002;30:652-659.

[2] Krustrup P, Dvorak J, Junge A, and Bangsbo J. Executive summary: the health and fitness benefits of regular participation in small-sided football games. Scand J Med Sci Sports, 2010; 20:132-135.

[3] Basim AA. Comparative study of the relationship connectivity interface for some physical abilities and fundamental skills of the players clubs anbar and baghdad for teams class a football for season (20112012). Master thesis, faculty of physical education, university of Baghdad, 2012.

[4] Ashley $\mathrm{P}$, Iorio $\mathrm{AD}$, Cole $\mathrm{E}$, Tanday $\mathrm{A}$, and Needleman I. Oral health of elite athletes and association with performance: a systematic review. $\mathrm{Br}$ J Sports Med, 2014; 49:14-19.

[5] Tozoglu S, and Tozoglu U. A one-year review of craniofacial injuries in amateur soccer players. J Craniofac Surg, 2006;17:825-827.

[6] Needleman I, Ashley P, Petrie A, Fortune F, Turner W, Jones J, Niggli J, Engebretsen L, Budgett R, Donos N, Clough T, and Porter S. 2013: Oral health and impact on performance of athletes participating in the London 2012 Olympic Games-a cross sectional study. Br J Sports Med, 47:1054-1058.

\section{Volume 6 Issue 12, December 2017}




\section{International Journal of Science and Research (IJSR) \\ ISSN (Online): 2319-7064 \\ Index Copernicus Value (2016): 79.57 | Impact Factor (2015): 6.391}

[7] Cullinan MP, and Seymour GJ. (2013): Periodontal disease and systemic illness: will the evidence ever be enough? Periodontol 2000, 62:271-86.

[8] Cerulli G, Carboni A, Mercurio A, Perugini M, Becelli R. Soccer-related craniomaxillofacial injuries. J Craniofac Surg, 2002; 13:627-630.

[9] Huang B, Wagner M, Croucher R, Hector M. Activities related to the occurrence of traumatic dental injuries in 15- to 18-year-olds. Dental Traumatol, 2009; 25:64-68.

[10] Glendor U. Aetiology and risk factors related to traumatic dental injuries: A review of the literature. Dental Trau-matol, 2009;25:19-31.

[11] Academy for Sports Dentistry (ASD). (2013): Position statement: Mouth-guard mandate

[12] Paulo V, Andrea T, Alexandre C, Reinaldo B, Neide P. Sports dentistry: a perspective for the future. Rev Bras Educ Fis Esporte, 2014; 28:351-358.

[13] World Health Organization (WHO). Oral health survey, basic methods. 3rd ed. Geneva $(\mathrm{CH})$. World Health Organization; 1987.

[14] World Health Organization (WHO). Oral Health Surveys. Basic Methods. 4th ed. Geneva $(\mathrm{CH})$ : World Health Organization; 1997.

[15] Perunski S, Lang B, Pohl Y, Filippi A. Level of information concerning dental injuries and their prevention in Swiss basketball - a survey among players and coaches. Dent Traumatol; 2005;21:195200.

[16] Erhan D, Yagmur D, Ozkan O, and Gurhan D. Prevalence of dental trauma and mouthguard awareness among weekend warrior soccer players. Journal of Oral Science, 2015; 57: 191-194.

[17] Papakosta V, Koumoura F, Mourouzis C. Maxillofacial injuries sustained during soccer: incidence, severity and risk factors. Dent Traumatol, 2008; 24:193-196.

[18] Correa MB, Schuch HS, Collares K, Torriani DD, Hallal PC, and Demarco FF. Survey on the occurrence of dental trauma and preventive strategies among Brazilian professional soccer players. J Appl Oral Sci, 2010; 18:572-576.

[19] Flores MT, Anderson L, Andreasen JO, Bakland LK, Malmgren B, Barnett F. Guidelines for the management of traumatic dental injuries. II. Avulsion of permanent teeth. Dent Traumatol, 2007; 23:130136.

[20] Ilhan U, Arzu A, Nazan E, Fahinur Ertugrul, Ozant Oncag and Rengin Attin. Dental Trauma and Mouthguard Usage among Soccer Players in Izmir, Turkey. Dent J;2014; 2: 78-84.

[21] Perunski S, Lang B, Pohl Y, Filippi A. Level of information concerning dental injuries and their prevention in Swiss basketball - a survey among players and coaches. Dent Traumatol; 2005;21:195200.

[22] Levin L, Friedlander LD, Geiger SB. Dental and oral trauma and mouthguard use during sport activities in Israel. Dent Traumatol;2003;19:237-242.

[23] Yamada T, Sawaki Y, Tomida S, Tohnai I, Ueda M. Oral injury and mouthguard usage by athletes in Japan. Endod Dent Traumatol;1998;14:84-87.
[24] Chantaramanee A, Siangruangsaeng K, Chittaputta P, Daroonpan P, Jaichum P, Jommoon P, Laohachaiaroon P, Champeecharoensuk S, Sitthirat T, Samnieng P. Oral Health Status of the Professional Soccer Players in Thailand. Journal of Dentistry Indonesia, 2016; 23: $1-4$.

[25] Tapias MA, Jiménez-Garcia R, Lamas F, Gil AA. Prevalence of traumatic crown fractures to permanent incisors in a childhood population: Móstoles, Spain. Dent Traumatol;2003;19:119-122. 